\title{
A Research on the Relationship between Top Managers' Intelligence and Their Ideas about Business Process Reengineering: Consideration of Emotionality and Spirituality
}

\author{
Evren Ayranc1 ${ }^{1} \&$ Ayşegül Ertuğrul Ayranc1 ${ }^{2}$ \\ 1 Faculty of Economics and Administrative Sciences, Istanbul AREL University, Istanbul, Turkey \\ ${ }^{2}$ School of Applied Sciences, Istanbul AREL University, Istanbul, Turkey \\ Correspondence: Evren Ayranc1, Istanbul AREL University, Turkoba Mah. Erguvan Sok. No: 26/K 34537 \\ Tepekent-Buyukcekmece, Istanbul, Turkey. Tel: 90-532-405-4094. E-mail: evrenayranci@gmail.com
}

Received: July 30, 2015

Accepted: August 19, 2015

Online Published: September 25, 2015

doi:10.5539/ibr.v8n10p66

URL: http://dx.doi.org/10.5539/ibr.v8n10p66

\begin{abstract}
With its dramatic boosts to effectiveness and efficiency, Business Process Reengineering (BPR) is a crucial tool for business success, thus countless businesses in various industries are inspired to get its benefits. Though these benefits are heavily related to technical matters such as cost, speed and quality; there is also a human side associated with BPR. This study is interested in an odd dimension of this human side: top managers' emotional and spiritual intelligence. More precisely, top managers' emotional and spiritual intelligences are believed to be related with their ideas about the targets and critical success factors of BPR. This study not only scrutinizes this belief, but also fills in a great gap as the literature does not offer a similar research. The operationalization stage of the study includes data from top managers of businesses in İkitelli Organized Industrial Zone (OIZ) and the findings clearly point out that top managers' spiritual intelligence is strongly and positively related with their ideas about BPR whereas there is no connection between their emotional capabilities and their mentioned ideas.
\end{abstract}

Keywords: business process reengineering, emotional intelligence, spiritual intelligence, top managers, Turkey

\section{Introduction}

Business literature pays a special attention to top managers for many reasons. They are the ultimate decision-makers in any business, thus they have great influence on business issues and business survival itself. The integrative nature of the business context necessitates these people's skills to step in for various managerial issues such as conflict, risk, financial, human resources, technology, change, communication, marketing, accounting, innovation, and manufacturing management. In other words, the phrase manage everything is truly a natural phenomenon for top managers. This phenomenon, moreover, is not actually limited to formal issues, the social feature of the business context necessitates top managers to take informal aspects (organizational culture, climate, citizenship behavior...) into account. Despite the presence of a vast scientific struggle to regard top managers in relation with these informal aspects of the business, there is tender research to evaluate the possibility of relationships among top managers' psycho-social features, informal issues of the business, and business operations. The research further becomes rare if the emphasis is on the relationships between top managers' psycho-social features and formal business issues solely.

The current study makes a contribution to these studies and the contribution is tightly connected with a contemporary business subject: Business process reengineering (BPR). Current business world moves away from the classical assumptions of the contingency approach due to vast and sudden changes that may happen anytime, anywhere. This truth compels top managers to be ready for grand organizational changes to match their businesses with the current, but more importantly, with possible future contexts. An easy prescription for such changes is the facilitation of BPR. BPR's detailed focus on business operations and superficial approach towards psycho-social aspects of the business cause it to be considered as a technical tool. On the other hand, BPR requires worker and manager commitment and the top managers must actively lead this process. The authors of the current study expect this requirement, especially the need for top management, to be an interesting starting point to scrutinize the existence of relationships between top managers' psycho-social features and BPR. Due to the availability of measurement and operationalization purpose, top managers' emotional and spiritual 
intelligences are used as the proxies for their psycho-social features. As these people are expected to direct BPR, their ideas about this process are also asked. Briefly, the main concern is an investigation of the existence and properties of the relationship between their two types of intelligence and their ideas about BPR.

\section{Business Process Reengineering (BPR): Definitions and Importance}

There has been a vast interest towards automatization of industrial and commercial activities in the last few decades. This interest provoked a great deal of focus on some technical aspects of many subjects such as cost formation and allocation, manufacturing, effectiveness, efficiency, and quality. On the other hand, the success of this interest has been questioned especially in the 1980s (Loveman, 1988), which has started to be answered in the late 1990s with the general claim that business performance can actually be increased (Srivastava, Shervani, \& Fahey, 1999). The possibility of performance superiority encouraged many businesses to implement automatization, but the contemporary survival and competition required more radical approaches to overarch the limits of sole automatization, thus more complicated and inclusive implementations such as activity-based costing (e.g. Malmi, 1999) and total quality management (Powell, 1995) have started to be facilitated by many businesses, albeit these are claimed to be futile attempts in this current globalized business world (Barouch \& Kleinhans, 2015).

All these call for even a further radical approach, the Business Process Reengineering (BPR or Business Process Management-BPM), which has actually been voiced since 1990s (e.g. Hammer \& Champy, 1993) and is still uttered today (e.g. Jeston \& Nelis, 2014). Basically, BPR is a set of radical changes on business processes with a target: dramatic increases of fundamental business performance measures such as cost, quality, service or speed (Hammer \& Champy, 1993). These business processes are not limited to be physical; informational aspects are also considered, and information production and distribution processes are simultaneously emphasized (Davenport \& Stoddard, 1994). BPR is not solely a technical concept; management philosophy should shift from a one-track mind towards radicalism (Weske, 2012), which makes innovation a vital matter (Goksoy, Ozsoy, \& Vayvay, 2012). Although the mentioned shift is posited to render BPR a management tool according some scholars (e.g. Grover \& Malhotra, 1997), BPR is extensively defined as the system, which includes radical changes in all business processes while considering external environment to achieve competitive superiority in terms of cost, quality, customer satisfaction and many other issues (Stahl, 1998). This definition accepts that BPR is too wide to fit into the management realm solely (Drucker, 1993) and the changes or re-makings of the business processes are not enough, the relationships with the external environment must also be re-configured (Talwar, 1993). In this case, BPR can be perceived as an agent of organizational change.

This change is performed to have competitive superiority as mentioned, and the facilitators of superiority include methods to reduce costs, optimize resource utilization, shorten product development and introduction processes, and use total quality management effectively; all of which are essential to create value for customers (Vantrappen, 1992). More specifically, BPR includes methods such as process visualization (Martinsons, 1995), change management (Kettinger, James, Teng, \& Guha, 1997), process simulation (Zarei, 2001), benchmarking (Tka \& Ghannouchi, 2014), project management (Grover, 1999), and process measurement (Keong, 2013), which cross-functionally aim to remake or at least update each business process so that every activity starts to create an extra value while business members are empowered (Al-Mashari \& Zairi, 2000). The accumulation of added values creates an organization-wide aggregated value and this value is a strategic asset in order to provide competitive advantage. Therefore BPR is an agent of organizational change, but is also an agent of process-specific and organizational-level value creation tool. Its holistic feature prods the business into action in order to find or develop new capabilities, build or alter strategies, and make changes related to markets, products, or both (Thyagarajan \& Khatibi, 2004), thus BPR is simply crowned as a strategic tool.

All the facts explained so far point out that BPR can broadly be summarized as a technical issue involving the combination of process re-design, value creation and the use of information technology (Reijers \& Mansor, 2005) with some social aspects in terms of management and worker capabilities (Farrell, 1994). Despite its focus on technical features, BPR's human side is actually posited to be the most important point as people are behind every of its features. Being strategic, BPR starts with the intentions of top management and is actively applied by other business members, especially by workers. The key element is change in BPR, thus the attitudes of top managers and workers towards this change determine the fate of BPR. The premises of these attitudes are expectations from the change (Mossholder, Settoon, Armenakis, \& Harris, 2000) and the coherence between these expectations and perceived results obtained (Smith, 2005). The fear that managers or workers have for the change should be directed before implementing BPR, thus positive attitudes should be developed (Lines, 2005) so that workers (Morris \& Brandon, 1993) and managers (Amanquah \& Adjei, 2013) can fully commit themselves. Shortly, an organization-wide commitment is vital for BPR's success. 
For this commitment, key people of the business with regards to BPR can be determined in advance and can be convinced in favor of BPR (Stanton, Hammer, \& Power, 1992). These key people, whether managers or technical staff, may later be effective to encourage cooperation of others in the business. All business members can be convinced that the change that comes with BPR does not jeopardize their situations by involving everyone in the process and by using positive communication (Marjanovic, 2000). This involvement may be in the form of BPR teams, which consist of BPR insider and outsider business members as well as professional BPR consultants (Attaran, 2000). Positive effects of BPR on the business and these effects' individual reflections can also be explained to business members (Benner \& Tushman, 2003).

Managers must extensively be emphasized in this process. Similar to workers, managers may be afraid of losing their power, the status quo, or even their jobs (Ahadi, 2004), thus the solutions proposed in the prior paragraph can also be applied to empower management commitment. When the top management is the subject, however, commitment becomes more crucial than ever. BPR is a top-down issue (Janson, 1993), and the top management is the starting point alas management alone is not sufficient for BPR success. As mentioned, there can be a resistance to the change of BPR, and the solutions not only include technical aspects, but also an influential communication. This fact necessities a versatile leadership style along with dynamic managerial skills at top management level (Janson, 1993). Put other way, top managers should be capable of changing their current ideas, behaviors, and therefore their attitudes for the sake of BPR, should be motivated and should have independent-thinking skills; thus be able to perform variable, non-programmable tasks (Sutcliffe, 1999). These changes affect how managers form and deploy business strategies, appraise and reward performance, share business-related knowledge, and communicate (Attaran, 2000).

\section{The Significance of Emotional and Spiritual Intelligence}

Emotional and spiritual intelligence are prominent issues in the literature. Emotional intelligence (EI), which is an older subject than spiritual intelligence (SI) (Ayranci, 2010), is defined in many ways and is much scrutinized by scholars. This intelligence is first taken into consideration by Payne (1985) and is strictly limited to be the capability of coping up with basic emotions such as fear and desire, and the feeling of pain. After being almost untouched for approximately five years, Salovey and Mayer (1989) are the first to offer a scientific model in order to study EI deeply and they contend that EI is actually perceiving, decoding, using, and managing emotions. This definition is later followed by many others. A simple definition that belongs to Martinez (1997) posits that it is the ability of an individual to correctly and dynamically assess own emotional reasoning. Other scholars consider EI to be the ability of effective emotional perception (e.g. Elfenbein, Der Foo, \& Boldry, 2006), and successful emotional appraisal (Innes-Ker \& Niedenthal, 2002).

This variety of definitions is also similar to the variety of measurement approaches. There are multi-dimensional instruments such as EQ-I (Bar-On, 1997), and there exist some uni-dimensional and more specific tools-Emotional Stroop Test (Richards, French, \& Johnson, 1992), for example. There are also context-based modified versions of these instruments (e.g. Matsumoto, LeRoux, Wilson-Cohn, Raroque, \& Kooken, 2000; Ayranci, 2010).

The business context accentuates either managers or workers if EI is the question. The results achieved about workers are generally positive-EI helps workers to fight job-related stress (Jordan et al., 2002), increases the effectiveness of mentoring (Chun, Litzky, Sosik, Bechtold, \& Godshalk, 2010), and is very effective on workers' performance (Lopes, Grewal, Kadis, Gall, \& Salovey, 2006). The results about managers are also affirmative. EI is a facilitator in leadership process (Goleman, Boyatzis, \& McKee, 2013); is a vital factor of managers' health and performance in the business context (Slaski \& Cartwright, 2002); can be effective in increasing managers' performance by reducing managers' work-family role conflicts (Carmeli, 2003), conflicts with workers (Schlaerth, Ensari, \& Christian, 2013), and conflicts due to cultural differences (Gabel, Dolan, \& Cerdin, 2005).

This study involves BPR, which is an overall organizational change and considers top managers. Therefore, it is important to precisely shed light on managers' EI-organizational change relationship. The literature points out that EI of managers becomes important if the issue is the change of organization. The change, as mentioned before, should be initiated and managed while keeping an eye on innovation. Creativity is the premise of innovation and it is especially inspired by managers' EI. It is argued that this inspiration can be made towards many issues such as workers' identification, information gathering and distribution, idea generation and sharing, and idea implementation with the aim of successful organizational change (Zhou \& George, 2003).

The literature on leadership and change further stresses EI's importance. Transformational leadership is required for organizational change and EI is an inseparable ingredient of this leadership type (Sosik \& Megerian, 1999). A transformational leader can use own EI to gain legitimacy among workers in favor of organizational change 
(Smollan, 2011). This acceptance particularly results with a very bright organizational change when the leader possesses appropriate communication and empathy skills (Cook, Macaulay, \& Coldicott, 2004). Emotional expression capability can also foster visionary leadership to set up the path for organizational change (Groves, 2006), thus EI is also effective to map out how and to where the change will stir.

A summary for managers' EI-BPR relationship can be made at this point. Though some scholars (e.g. Liu \& Ma, 2012) consider BPR as a technical issue, some other scholars (e.g. Marjanovic, 2000; Goksoy et al., 2012) add psycho-social facts while subjecting BPR and a further step is the notion that emotional capabilities are effective players in the design (Becker, Kugeler, \& Rosemann, 2011) and implementation (Caya, Brunelle, Leger, \& Grebot, 2012) processes, and thus the success of BPR. All these processes result in an overall change and it has to be managed, which in turn, highlights managers' skills (Boeker, 1997) and exclusively their emotional capabilities (Attaran, 2000) as these capabilities-especially when leadership is applied in favor of BPR (Ahadi, 2004)-can enamor managers' commitment to BPR (Crowe, Fong, Bauman, \& Zayas-Castro, 2002) and be used to convince workers in favor of the change, which BPR brings with (Zaheer et al., 2010).

The other intelligence, spiritual intelligence (SI), is a newer issue for business context. The business context in fact makes it odd to consider spirituality and spiritual intelligence (SI) at first. A literature review, however, points out that there are indeed attempts to relate business with spiritual issues. A noteworthy example in this sense is the workplace spirituality, which is referred to as being in a positive mood in the workplace (Shaw, 1999) via the use of religiosity (Fernando \& Jackson, 2006), a combination of religiosity and psychology (Sutcliffe \& Bowman, 2000) or maybe none of these (Briskin, 1998). Some scholars also posit that spirituality and religiosity should be separated in general (e.g. Dowling et al., 2004) and in the business context (e.g. Ayranci \& Semercioz, 2011).

At the beginning of 2000s, spirituality starts to be questioned and scholars (Emmons, 2000) claim spirituality to be a distinct type of human capability. Similar to consciousness, SI is defined as an individual's capacity to have a sense of sacredness, virtue, and the awareness that everything is interconnected in the universe (Emmons, 2000). Other than this definition, it is simply considered to be the capacity to question the reasons of everything (Sisk, 2008) or the capability to connect to a higher power, who is the main source of every entity (Vaughan, 2002).

Spiritual intelligence or even distinct spiritual capabilities are very new concepts in the literature, thus there are very few instruments available. Examples include Psycho-Matrix Spirituality Inventory (PSI) (Yang \& Mao, 2007), Spiritual Intelligence Scale (SIS) (Tirri, Nokelainen, \& Ubani, 2006), and Integrated Spiritual Intelligence Scale (ISIS) (Amram \& Dryer, 2008).

Besides being new, difficulties to relate spirituality with business issues resolve the SI research in business context even harder. Very few studies find out that top managers' spiritual capabilities are partly effective on the business performance (Ayranci, 2010), spirituality and spiritual capabilities are different when top managers are considered (Ayranci \& Semercioz, 2011), spiritual leadership features of the family member top managers can affect their family businesses (Dede \& Ayranci, 2014), this intelligence is beneficial in the process of transformational leadership development (Hasani, Alam, \& Sepasi, 2013), and managers' spiritual capabilities can be used to inspire workers towards organizational goals (Zarei Matin, Kheirandish, \& Jahani, 2010). Shortly, spiritual capabilities are important actors of management and leadership. Like the case with EI, managers' SI or at least workplace spirituality are denoted to affect organizational changes positively (e.g. Fry \& Cohen, 2009) and therefore, SI is expected to be related to BPR.

\section{Methodology}

As mentioned before, the main purpose of this research is to find out traces of relationships among top managers' EI, SI, and their ideas about BPR, which is modeled in Figure 1. A questionnaire is prepared and applied to top managers of the businesses in the biggest organized industrial zone (OIZ) of Turkey, the İkitelli OIZ, which hosts 27301 businesses (IOSB, 2012). The sample size is calculated to be 379 with a 5\% margin of error and $95 \%$ confidence level (Raosoft, 2004). Because of possible obsolete or missing data, 400 questionnaires are used for data collection process. This process is performed with the help of a professional consulting firm, which applies the questionnaires and returns the filled-in questionnaires to the authors. As per request of the authors, the firm also provides a list of the participants with their contact information. The authors phone each participant to check whether the questionnaires are really applied. 


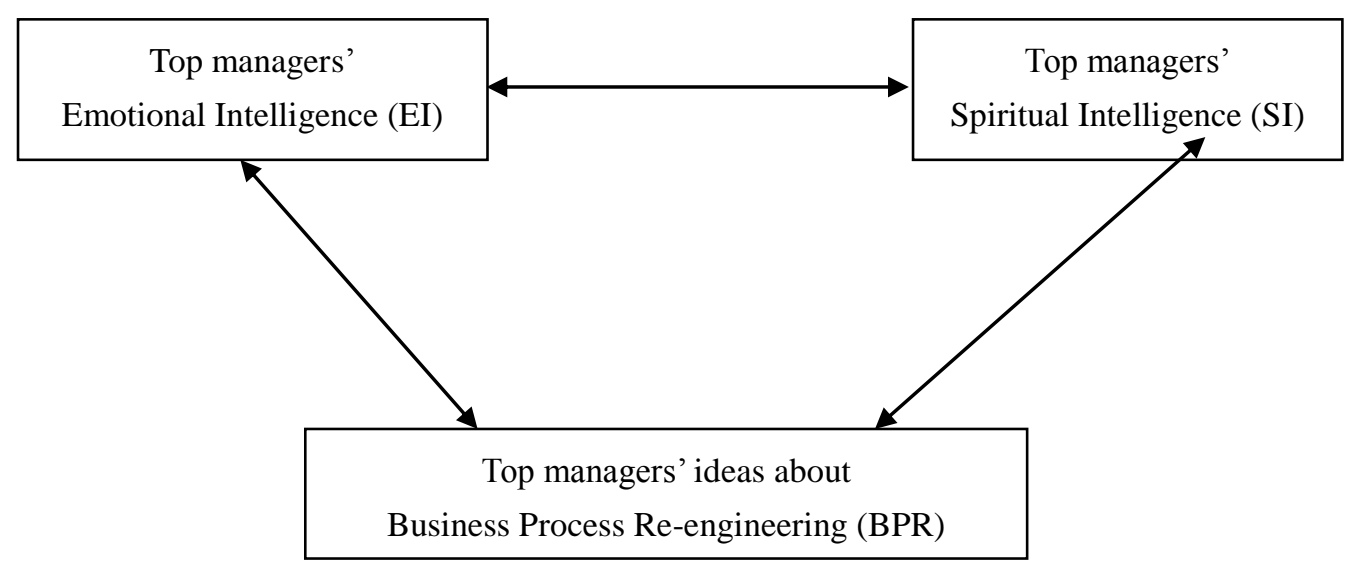

Figure 1. The proposed research model

The authors also consider that the top managers of big businesses should solely participate in the research for the sake of more realistic data collection. In other words, small and medium-sized enterprises (SMEs) are posited to have great difficulties for BPR facilitation (Browne \& O'Sullivan, 2013) especially in the Middle Eastern context (e.g. Imanipour, Talebi, \& Rezazadeh, 2012), thus the possibility of BPR planning and implementation decreases when SMEs are focused rather than big businesses. This urges the authors to expect that managers of SMEs may have wrong, prejudiced or missing information regarding BPR and thus, they may show reluctance while filling in the questionnaires. Because of this expectation, the formal definition of SME in Turkey (Official Gazette, 2012) is written at the top of the questionnaire and the participating top manager is asked to evaluate own business accordingly. The answers are noted only if the business is not considered to be an SME by the top manager. This greatly limits the number of businesses and 126 questionnaires with a negative response to the SME definition are taken into consideration.

After a short introduction and the SME definition, the questionnaire starts with the items of spiritual and emotional intelligence. SI items originally belong to Amram and Dryer's (2008) Integrated Spiritual Intelligence Scale while EI items are taken from EQ-I, which is developed by Bar-On (1997). The prior research (e.g. Ayranci, 2010) proof that these constructs can not completely be used as-is in the Turkish context force the authors to perform explanatory factor analyses. The top managers' ideas about BPR are twofold: what the aim of BPR should be and what critical factors are vital for BPR. A combination of the studies of Al-Mashari and Zairi (1999), and Jinjiri et al. (2012) is made to consider BPR. Again, an exploratory factor analysis is performed to find out the statistical structure of ideas about BPR. All these analyses are performed in the form of principal components analysis with varimax rotation. Factor loadings smaller than 0.5 are suppressed.

Initial findings suggest that SI of the top managers is made up of two factors, which aggregately explains $57.905 \%$ of the overall data. Participants' EI, on the other hand, is divided into three factors, which can cover $69.098 \%$ of all data. The factor loadings of the items and the results of reliability analyses are given in Table 1.

Table 1. Results of the explanatory factor and reliability analyses of top managers' SI and EI

\begin{tabular}{lcc}
\hline SI Factors & $\begin{array}{c}\text { Higher Consciousness } \\
\text { (SI_HIGH) }\end{array}$ & $\begin{array}{c}\text { Self-Consciousness } \\
\text { (SI_SELF) }\end{array}$ \\
\hline Availability for explanatory factor analysis & $\begin{array}{c}\text { KMO Value: } \mathbf{0 . 8 9 4} \\
\text { Bartlett's test value is statistically significant. }\end{array}$ \\
\hline Variance explained (\%) & $\mathbf{3 0 . 8 6 6}$ & $\mathbf{2 7 . 0 3 9}$ \\
Cronbach's Alpha Value & $\mathbf{0 . 8 4 7}$ & $\mathbf{0 . 8 5 2}$ \\
Overall Cronbach's Alpha Value & \\
I am aware of a wise- or higher-self in me that I listen to for guidance. & 0.777 \\
(SI_H1) & \\
In my day-to-day tasks, I pay attention to that which cannot be put into & 0.733 \\
words, such as indescribable sensual or spiritual experiences. (SI_H2) & \\
I listen deeply to both what is being said and what is not being said. (SI_H3) & 0.725 \\
I listen to my gut feeling or intuition in making important choices. (SI_H4) & 0.672 \\
\hline
\end{tabular}




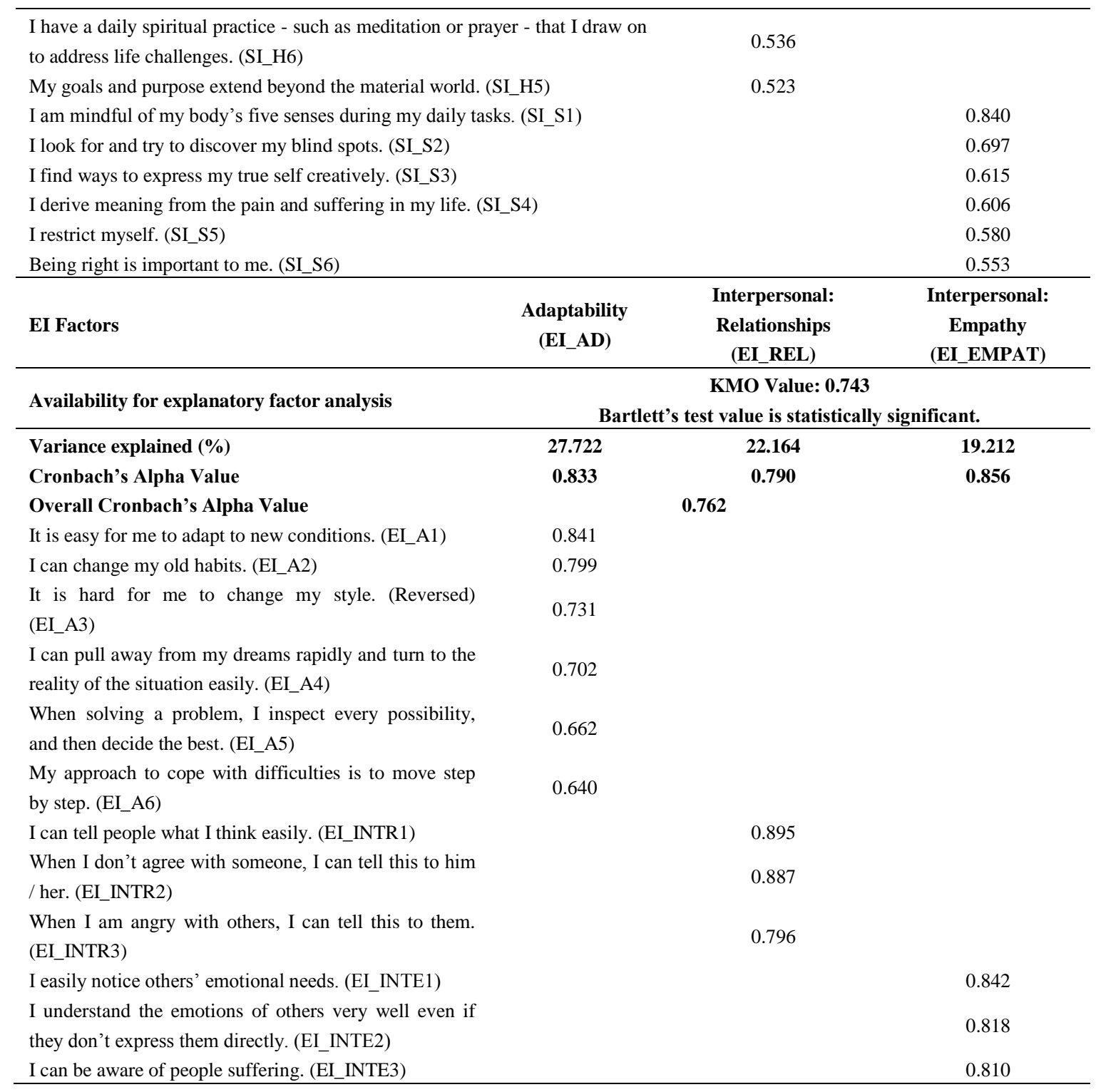

Although the statistical structures of SI and EI are different than the ones emerged in Ayranci's (2010) study, some factors are preserved. SI is composed of the higher consciousness, which unveils the belief towards immateriality and a higher self-being, and the self-consciousness, which is actually related to the participants' knowledge and awareness about oneself. EI includes the adaptability capability of the participant while interpersonal aspects address the participants' capacity to recognize others' emotions and the extent to which the participant can frankly interact with others.

The next step is to find out how the ideas of top managers about BPR are shaped. Table 2 points out that there is a four-tier structure, which explains $55.253 \%$ of the total variance and confirms that the factors and the whole structure are reliable. 
Table 2. Results of the explanatory factor and reliability analyses of top managers' ideas about BPR

\begin{tabular}{|c|c|c|c|c|}
\hline & $\begin{array}{c}\text { Strategic } \\
\text { Dimension } \\
\text { (BPR_ST) }\end{array}$ & $\begin{array}{c}\text { Change } \\
\text { Dimension } \\
\text { (BPR_CH) }\end{array}$ & $\begin{array}{c}\text { Operational } \\
\text { Dimension } \\
\text { (BPR_OP) }\end{array}$ & $\begin{array}{c}\text { BPR Aims } \\
\text { (BPR_AIM) }\end{array}$ \\
\hline \multirow{2}{*}{ Availability for explanatory factor analysis } & \multicolumn{4}{|c|}{ KMO Value: 0.679} \\
\hline & \multicolumn{4}{|c|}{ Bartlett's test value is statistically significant. } \\
\hline Variance explained $(\%)$ & 15.451 & 14.624 & 13.766 & 11.412 \\
\hline Cronbach's Alpha Value & 0.674 & 0.704 & 0.611 & 0.568 \\
\hline Overall Cronbach's Alpha Value & \multicolumn{4}{|c|}{0.649} \\
\hline Top management support is vital for BPR success. (B_ST1) & 0.730 & & & \\
\hline Leadership is vital for BPR success. (B_ST2) & 0.720 & & & \\
\hline Work environment and culture is vital for BPR success. (B_ST3) & 0.641 & & & \\
\hline Quality improvement system is vital for BPR success. (B_ST4) & 0.550 & & & \\
\hline Technology transfer and use is vital for BPR success. (B_ST5) & 0.518 & & & \\
\hline $\begin{array}{l}\text { Acceptance and performance of change management is vital for BPR success. } \\
\text { (B_CH1) }\end{array}$ & & 0.839 & & \\
\hline $\begin{array}{l}\text { New process, product and service design or development is vital for BPR } \\
\text { success. (B_CH2) }\end{array}$ & & 0.672 & & \\
\hline People skill interchangeability is vital for BPR success. (B_CH3) & & 0.653 & & \\
\hline Resource value addition process is vital for BPR success. (B_CH4) & & 0.599 & & \\
\hline Productivity improvement is vital for BPR success. (B_OP1) & & & 0.742 & \\
\hline Resource preservation and utilization is vital for BPR success. (B_OP2) & & & 0.722 & \\
\hline Managing resistance to change is vital for BPR success. (B_OP3) & & & 0.652 & \\
\hline $\begin{array}{l}\text { Optimally utilizing the resources and reducing costs, and leading to reduction } \\
\text { in operating budget should be BPR's target. (B_AIM1) }\end{array}$ & & & & 0.818 \\
\hline $\begin{array}{l}\text { Formulating practical targets (business process goals), and focusing on } \\
\text { achieving end results and objectives should be BPR's target. (B_AIM2) }\end{array}$ & & & & 0.641 \\
\hline $\begin{array}{l}\text { Use of time as a competitive weapon (by decreasing cycle time and optimally } \\
\text { utilizing man-hour) should be BPR's target. (B_AIM3) }\end{array}$ & & & & 0.591 \\
\hline
\end{tabular}

Factors in Table 2 are named according to Al-Mashari and Zairi (1999), and Jinjiri et al.'s (2012) studies. A noteworthy outcome is that the top managers attribute a significant importance to managerial dimensions of BPR. Another eye-catching point is the emphasis on human side of BPR almost in every factor. All these are promising for the authors as their expectations to come up with some relationships among EI, SI, and ideas about BPR rise.

The final step is to investigate these expected relationships. The investigation is performed by structural equation modeling (SEM) and second-level latent variables are used after the proposed model in Figure 1 is further expanded. The expanded model is presented in Figure 2. 


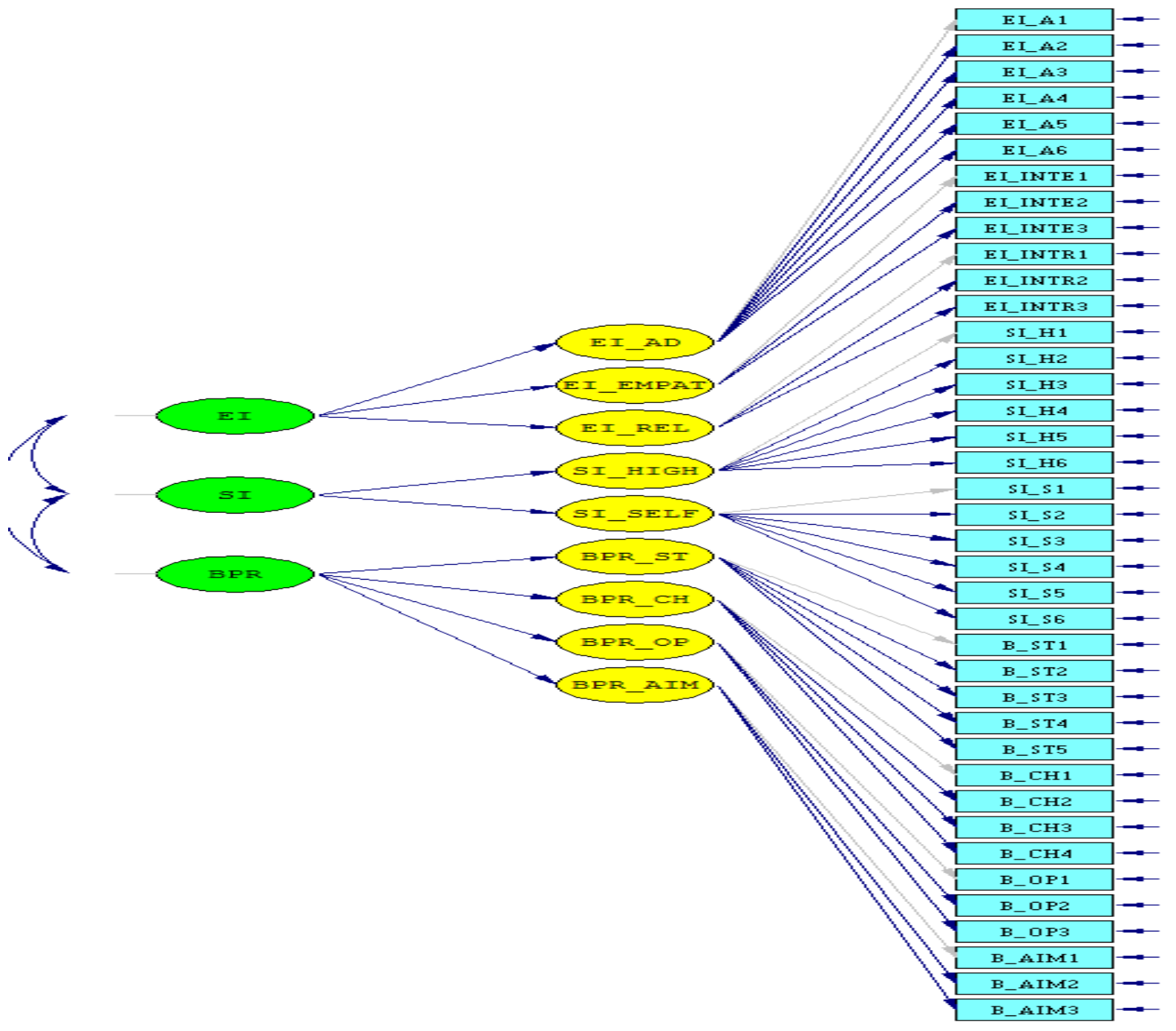

Figure 2. The proposed research model (Expanded)

(See Tables 1 and 2 for abbreviations)

The expanded proposed model seems to be realistic (RMSEA: 0.072 and stem-leaf and Q-plots of standardized residuals denoting a normal distribution in Figure 3).
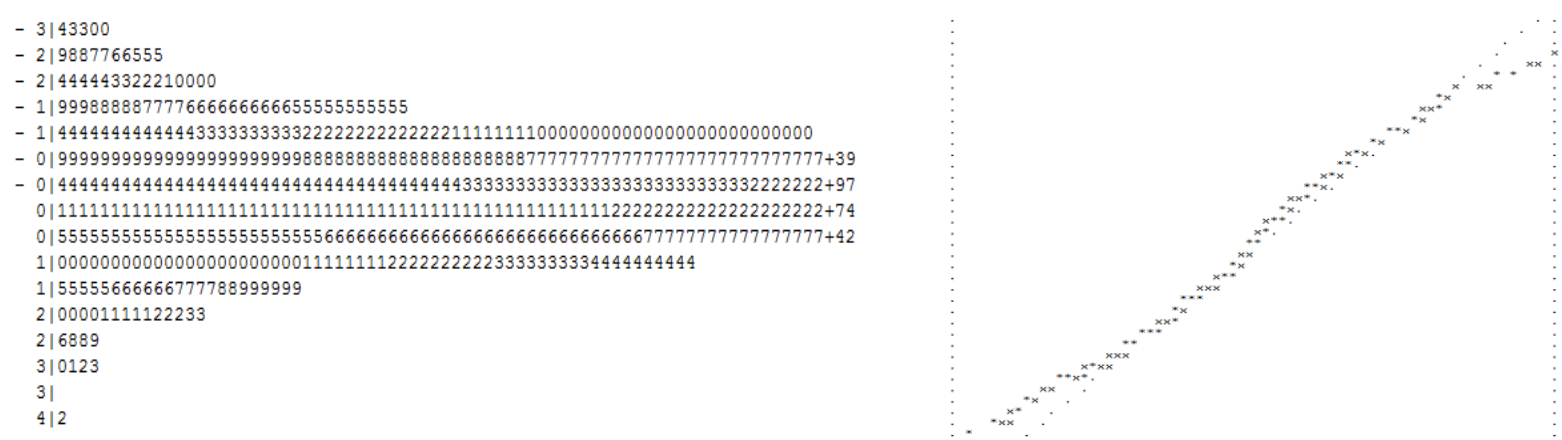

Figure 3. The Stem-Leaf and Q-Plots of standardized residuals 
Despite being realistic, an instant finding is that the operational dimension is not significantly related to BPR when the entire model is assessed (Equation 9). In other words, the participants solely note the strategic and change dimensions, and the aims of BPR when BPR is to be considered in relationship with their emotional and spiritual intelligence.
(EI) Adaptability $=0.092 *$ Emotional Intelligence, Errorvar. $=1.06, \mathrm{R}^{2}=0.0080$ $(0.025) \quad(0.20)$ 3.66

(EI) Interpersonal, Empathy $=0.078^{*}$ Emotional Intelligence, Errorvar. $=0.91, \mathrm{R}^{2}=0.0066$ $(0.025)$

3.12

3.32

(EI) Interpersonal, Relationships $=0.44 *$ Emotional Intelligence, Errorvar. $=0.11, \mathrm{R}^{2}=0.63$

$$
\text { (0.088) (0.042) }
$$

$$
2.56
$$

(SI) Higher Consciousness $=0.98 *$ Spiritual Intelligence, Errorvar. $=0.29, \mathrm{R}^{2}=0.95$

6.86

(SI) Self-Consciousness $=0.96 *$ Spiritual Intelligence, Errorvar. $=0.33, \mathrm{R}^{2}=0.85$
$(0.19)$
5.15
$(0.081)$
7.59

$(\mathrm{BPR})$ Strategic Dimension $=1.09 *$ Ideas about BPR, Errorvar. $=0.92, \mathrm{R}^{2}=0.83$

$(0.39)$

23.59

$(\mathrm{BPR})$ Change Dimension $=0.60 *$ Ideas about BPR, Errorvar. $=1.93, \mathrm{R}^{2}=0.16$

$\begin{array}{lc}(0.17) & (0.47) \\ 3.58 & 4.09\end{array}$

$(\mathrm{BPR}) \mathrm{BPR}$ Aims $=0.79 *$ Ideas about BPR, Errorvar. $=0.11, \mathrm{R}^{2}=0.23$ $(0.039) \quad(0.046)$

$$
8.52 \quad 2.59
$$

$(B P R)$ Operational Dimension $=0.14 *$ Ideas about BPR, Errorvar. $=2.59, R^{2}=0.0073$ $\begin{array}{ll}(0.20) & (0.97) \\ 0.70 & 2.66\end{array}$

The equations also reveal that some of the relationships between the factors and their respective concepts are weak. The interpersonal relationships seems to be the most active factor within EI, and this suggests that the participants-the top managers-pay most of their attention to human interactions. Its relationship with EI is also positive, therefore the top managers posit that it contributes positively to their emotional capabilities. Though the two other factors, adaptability and empathy have weaker relationships with participants' EI, their contributions are also positive. The factors of SI, self and higher consciousness, have positive and strong relationships with SI. Thus the top managers unveil their awareness about a higher power and their own beings when these are included within the overall model. Contrary to emotional and spiritual intelligence, BPR is taken into account by solely three factors in the model as already mentioned. Of these, strategic dimension is the most powerfully connected factor with the ideas about BPR and its contribution is also notably higher when compared with the other factors. The authors consider that the findings about the ideas related to BPR are very much expected. Precisely, it is natural for the top managers to mostly emphasize the strategic dimension of BPR as they are already the members of their businesses' strategic cadre. This cadre also necessitates taking on duties for an overall organizational change and thus, the change dimension should be regarded. The strategic cadre obligates an overall look on the business and the operations of BPR are generally lower management's duty; thus the operational dimension is not much catchy for the top managers. Finally, the aims of BPR affect the entire business, and this can cause the top managers' interest to accumulate on these aims.

The final step is to check the proposed model, the relationships among SI, EI and the ideas about BPR. The correlations presented in Table 3 point out that the top managers' emotional and spiritual intelligence are not connected when the proposed model is tested. Their emotional intelligence, moreover, is not related with their ideas about business process reengineering. On the other hand, there is a positive and strong correlation between the top managers' spiritual intelligence and their ideas about business process reengineering. 
Table 3. The relationships among the top managers' emotional and spiritual intelligences, and ideas about BPR

\begin{tabular}{cccc}
\hline & $\begin{array}{c}\text { Emotional } \\
\text { Intelligence }\end{array}$ & $\begin{array}{c}\text { Spiritual } \\
\text { Intelligence }\end{array}$ & Ideas about BPR \\
\hline Emotional Intelligence & $\mathbf{1 . 0 0}$ & & \\
Spiritual Intelligence & -0.02 & & \\
& $(0.02)$ & $\mathbf{1 . 0 0}$ & \\
& -1.00 & & \\
Ideas about BPR & 0.00 & 0.75 & $\mathbf{1 . 0 0}$ \\
& $(0.02)$ & $(0.06)$ & \\
\hline
\end{tabular}

The authors believe that Table 3 indicates many implications. The top managers' EI is made up of their adaptability capacity and their interpersonal skills. The authors consider that the technical nature of BPR (with its strategic and change dimensions along with technical aims) may be responsible for EI-BPR disconnection-the top managers may have simply not found a common or a similar point between their emotionality-based psycho-social capacities and the technical aspects of BPR. Another implication is about the two intelligences, the top managers consider emotional and spiritual intelligences to be distinct capacities. This outcome is not expected by the authors, especially when there are proofs for their connections in the literature (e.g. Ayranci, 2010). It is, however, important to recall that their connection is checked in an integrative model, proposed for the first time in this study. Therefore the authors believe that the holistic and integrative nature of the model may be a cause for this disconnection. Another possibility may be about the technical content of the ideas about BPR; this content may have blurred the focus on human side and thus the possible connections between these two intelligences. A last possibility for this disconnection may be related to references. Both emotional and spiritual intelligences directly address the top manager, whereas the ideas of the top managers about BPR directly address the business. This difference in addressing may have led the participants to assume that their intelligences' connections and their ideas about BPR are completely separate issues.

A final and a very interesting finding is that the top managers' spiritual intelligence and their ideas about BPR are related with each other, and moreover, this is a positive and strong relationship. Though the authors expect both intelligences to be simultaneously related with the ideas about BPR; emotional intelligence's disconnection and spiritual intelligence's connection exactly puzzles the authors at first, albeit the contents of spiritual intelligence and the ideas about BPR decrease this confusion.

Spiritual intelligence includes the self and higher consciousness. A detailed look reveals that higher consciousness is made up of top managers' prescription for guidance; sensuality and spirituality for routine tasks, decision-making, listening, addressing challenges, and personal goals. All of these can briefly be named as the top managers' use of spirituality for their own actions and decision-making processes. The three factors that make up the ideas about BPR belong to these participants and these factors propound that BPR is profoundly a top management duty. These inferences lead to the thought that the top managers are willing to articulate a connection between their spirituality capacity and their BPR duty.

The other factor, self-consciousness, is about the top managers' awareness of own weaknesses and senses, personal life interpretation and restriction, emphasis on being right, and own expression. These issues aggregately point out top managers' self-awareness, and similar to the case with the higher consciousness, the top managers deliberate a connection between their perceptions of own features and their possible compulsion of leading the BPR process.

\section{Conclusion and Recommendations}

This study addressed a relationship with a unique nature-between top managers' emotional and spiritual capacities, and their ideas about a technical matter: BPR. This human and technical aspects' relationship analysis revealed an interesting result. The top managers' own adaptability, empathy and open communication capacities are not related to their ideas about BPR. On the contrary, spiritual issues-the self and higher consciousness-are related with the ideas about BPR and the reason is considered to be top managers' belief that own spirituality and self-recognition should be taken into account if BPR's strategic and change dimensions along with its aims are to be decided by their own.

The mentioned unique nature resolves this study a preliminary research and there is no any other study to make a comparison. A quick suggestion, in this case, is to test the proposed model in various contexts such as different 
organized industrial zones, sectors and business types. Besides an extensive research on any possible effects of these different contexts, the same model can also be tested in the international environment, thus country-based comparisons can be performed. The model can further be expanded and issues such as religiosity, social and organizational culture, and organizational climate may be added in. In other words, any relationship between the technical issues of BPR and psycho-social aspects can overarch the dominance of top managers' emotional and spiritual capacities. Considering different participants may also be noteworthy; BPR specialists are the immediate obligators of the process and therefore an analysis of their intelligences' connections with their attitudes towards BPR may uncloak absorbing results. The model tests may also be performed across top manager, middle level manager, and specialist groups in order to catch similarities or differences. All these implications and suggestions lead to a specific point: human side of BPR should extensively be scrutinized and this probe should involve spiritual issues in the workplace.

\section{References}

Ahadi, H. R. (2004). An examination of the role of organizational enablers in business process reengineering and the impact of information technology. Information Resources Management Journal, 17(4), 1-19. http://dx.doi.org/10.4018/irmj.2004100101

Al-Mashari, M., \& Zairi, M. (1999). Business process reengineering implementation processes: An analysis of key success and failure factors. Business Process Management Journal, 5(1), 87-112. http://dx.doi.org/10.1108/14637159910249108

Al-Mashari, M., \& Zairi, M. (2000). Revisiting BPR: A holistic review of practice and development. Business Process Management Journal, 6(1), 10-42. http://dx.doi.org/10.1108/14637150010283045

Amanquah, B., \& Adjei, K. S. (2013). Business process reengineering (BPR) in the financial services sector: A Case study of Ghana commercial bank (GCB) limited. European Journal of Business and Management, 5(29), 59-66.

Amram, J. Y., \& Dryer, C. (2008). The integrated spiritual intelligence scale (ISIS): Development and preliminary validation. Paper presented at the 116th Annual Conference of the American Psychological Association, Boston, 14-17 August 2008. Retrieved from http://www.yosiamram.net/docs/ISIS_APA_Paper_Presentation_2008_08_17.pdf

Attaran, M. (2000). Why does reengineering fail? A practical guide for successful implementation. The Journal of Management Development, 19(9), 794-801. http://dx.doi.org/10.1108/02621710010378237

Austin, A. (2007). Change management excellence: Using the four intelligences for successful organizational change. Leadership and Organization Development Journal, 28(3), 291-292. http://dx.doi.org/10.1108/01437730710739701

Ayranci, E. (2010). Effects of Turkish top managers' emotional and spiritual intelligences on their organizations' financial performance. China-USA. Business Review, 9(11), 50-73.

Ayranci, E., \& Semercioz, F. (2011). The Relationship between spiritual leadership and issues of spirituality and religiosity: A study of top Turkish managers. International Journal of Business and Management, 6(4), 136-149. http://dx.doi.org/10.5539/ijbm.v6n4p136

Bar-On, R. (1997). BarOn Emotional Quotient Inventory Technical Manual. Toronto: MHS Publications.

Barouch, G., \& Kleinhans, S. (2015). Learning from criticisms of quality management. International Journal of Quality and Service Sciences, 7(2/3), 201-216. http://dx.doi.org/10.1108/IJQSS-02-2015-0026

Becker, J., Kugeler, M., \& Rosemann, M. (2011). Process management: A guide for the design of business processes. Germany: Springer-Verlag Berlin Heidelberg. http://dx.doi.org/10.1007/978-3-642-15190-3

Benner, M. J., \& Tushman, M. L. (2003). Exploitation, exploration, and process management: The productivity dilemma revisited. Academy of Management Review, 28(2), 238-256. http://dx.doi.org/10.5465/AMR.2003.9416096

Boeker, W. (1997). Strategic change: The influence of managerial characteristics and organizational growth. Academy of Management Journal, 40(1), 152-170. http://dx.doi.org/10.2307/257024

Briskin, A. (1998). The Stirring of Soul in the Workplace. San Francisco: Jossey-Bass.

Browne, J., \& O'Sullivan, D. (2013). Re-engineering the Enterprise. Germany: Springer.

Carmeli, A. (2003). The relationship between emotional intelligence and work attitudes, behavior and outcomes: 
An examination among senior managers. Journal of Managerial Psychology, 18(8), 788-813. http://dx.doi.org/10.1108/02683940310511881

Caya, O., Brunelle, E., Leger, P. M., \& Grebot, T. (2012). An empirical study on emotions, knowledge management processes, and performance within integrated business process teams. Paper presented at the 45th Hawaii International Conference on System Sciences, Hawaii, 4-7 January 2012. http://dx.doi.org/10.1109/HICSS.2012.98

Chun, J. U., Litzky, B. E., Sosik, J. J., Bechtold, D. C., \& Godshalk, V. M. (2010). Emotional intelligence and trust in formal mentoring programs. Group Organization Management, 35(4), 421-455. http://dx.doi.org/10.1177/1059601110378293

Cook, S., Macaulay, S., \& Coldicott, H. (2004). Change Management Excellence: Using the Four Intelligences for Successful Organizational Change. USA: Kogan Page Publishing

Crowe, T. J., Fong, F. M., Bauman, T. A., \& Zayas-Castro, J. L. (2002). Quantitative risk level estimation of business process reengineering efforts. Business Process Management Journal, 8(5), 490-511. http://dx.doi.org/10.1108/14637150210449148

Davenport, T. H., \& Stoddard, D. B. (1994). Reengineering: Business change of mythic proportions? MIS Quarterly, 18(2), 121-127. http://dx.doi.org/10.2307/249760

Dede, N. P., \& Ayranci, E. (2014). Exploring the connections among spiritual leadership, altruism and trust in family businesses. Quality and Quantity, 48(6), 3373-3400. http://dx.doi.org/10.1007/s11135-013-9962-x

Dowling, E. M., Gestsdottir, S., Anderson, P. M., Von Eye, A., Almerigi, J., \& Lerner, R. M. (2004). Structural relations among spirituality, religiosity, and thriving in adolescence. Applied Developmental Science, 8(1), 7-16. http://dx.doi.org/10.1207/S1532480XADS0801_2

Drucker, P. F. (1993). Post-capitalist Society. Oxford: Butterworth-Heinemann.

Elfenbein, H. A., Der Foo, M., \& Boldry, J. G. (2006). Dyadic effects in nonverbal communication: A variance partitioning analysis. Cognition and Emotion, 20, 149-159. http://dx.doi.org/10.1080/02699930500339908

Emmons, R. A. (2000). Is spirituality intelligence? Motivation, cognition, and the psychology of ultimate concern. International Journal for the Psychology of Religion, 10(1), 3-26. http://dx.doi.org/10.1207/S15327582IJPR1001_2

Farrell, J. (1994). A practical guide for implementing reengineering. Planning Review, 22(2), 40-45. http://dx.doi.org/10.1108/eb054461

Fernando, M., \& Jackson, B. (2006). The influence of religion-based workplace spirituality on business leaders' decision-making: An inter-faith study. Journal of Management and Organization, 12(1), 23-39. http://dx.doi.org/10.5172/jmo.2006.12.1.23

Fry, L. W., \& Cohen, M. P. (2009). Spiritual leadership as a paradigm for organizational transformation and recovery from extended work hours cultures. Journal of Business Ethics, 84(2), 265-278. http://dx.doi.org/10.1007/s10551-008-9695-2

Gabel, R. S., Dolan, S. L., \& Cerdin, C. L. (2005). Emotional intelligence as predictor of cultural adjustment for success in global assignments. Career Development International, 10(5), 375-395. http://dx.doi.org/10.1108/13620430510615300

Goksoy, A., Ozsoy, B., \& Vayvay, O. (2012). Business process reengineering: Strategic tool for managing organizational change an application in a multinational company. International Journal of Business and Management, 7(2), 89-112. http://dx.doi.org/10.5539/ijbm.v7n2p89

Goleman, D., Boyatzis, R., \& McKee, A. (2013). Primal Leadership: Unleashing the Power of Emotional Intelligence. USA: Harvard Business Press.

Grover, V. (1999). From business reengineering to business process change management: A longitudinal study of trends and practices. IEEE Transactions on Engineering Management, 46(1), 36-46. http://dx.doi.org/10.1109/17.740036

Grover, V., \& Malhotra, M. K. (1997). Business process reengineering: A tutorial on the concept, evolution, method, technology and application. Journal of Operations Management, 15(3), 193-213. http://dx.doi.org/10.1016/S0272-6963(96)00104-0

Groves, K. S. (2006). Leader emotional expressivity, visionary leadership, and organizational change. 
Leadership \& Organization Development Journal, 27(7), 566-583. http://dx.doi.org/10.1108/01437730610692425

Hammer, M., \& Champy, J. A. (1993). Reengineering the Corporation: A Manifesto for Business Revolution. New York: Harper Collins.

Hasani, E., Alam, S., \& Sepasi, H. (2013). Relationship of emotional and spiritual intelligences with transformational leadership in the sports managers of Alborz Province. Annals of Biological Research, 4(8), 205-210.

Herman, V. (1992). Creating customer value by streamlining business processes. Long Range Planning, 25, 53-62. http://dx.doi.org/10.1016/0024-6301(92)90310-X

Imanipour, N., Talebi, K., \& Rezazadeh, S. (2012). Business Process Management (BPM) Implementation and Adoption in SMEs: Inhibiting Factors for Iranian E-Retail Industry. Retrieved from http://papers.ssrn.com/sol3/Delivery.cfm/SSRN_ID1990363_code1186647.pdf?abstractid=1990363\&mirid $=1(24.06 .2015)$

Innes-Ker, A., \& Niedenthal, P. M. (2002). Emotion concepts and emotional states in social judgment and categorization. Journal of Personality and Social Psychology, 83(4), 804-816. http://dx.doi.org/10.1037/0022-3514.83.4.804

IOSB. (2012). IOSB General Information (In Turkish). Retrieved from http://www.iosb.org.tr/v3/index.php?option=com_content\&view=article\&id=7\&Itemid=25 (09.06.2015)

Janson, R. (1993). How reengineering transforms organizations to satisfy customers? National Productivity Review, 12(1), 45-53. http://dx.doi.org/10.1002/npr.4040120107

Jeston, J., \& Nelis, J. (2014). Business Process Management. New York: Routledge.

Jinjiri, R. K., Rizal, R. M., \& Norelena, H. (2012). Critical Success factors for Business Process Management for Small and Medium Banks in Nigeria. Business and Management Review, 2(1), 83-91.

Jordan, P. J., Ashkanasy, N. M., Charmine, E. J., \& Hartel, C. E. J. (2002). Emotional intelligence as a moderator of emotional and behavioral reactions to job insecurity. Academy of Management Review, 27(3), 361-372. http://dx.doi.org/10.5465/AMR.2002.7389905

Keong, C. K. (2013). Are PMS meeting the measurement needs of BPM? A literature review. Business Process Management Journal, 19(3), 535-574. http://dx.doi.org/10.1108/14637151311319941

Kettinger, W. J., James, W. J., Teng, T. C., \& Guha, S. (1997). Business process change: A study of methodologies, techniques, and tools. MIS Quarterly, 21(1), 55-80. http://dx.doi.org/10.2307/249742

Lines, R. (2005). The structure and function of attitudes toward organizational change. Human Resource Development Review, 4(1), 8-32. http://dx.doi.org/10.1177/1534484304273818

Liu, Z., \& Ma, C. (2012). Study on SMEs business process reengineering in e-commerce environment. Journal of Applied Library and Information Science, 1(2), 33-38.

Lopes, P. N., Grewal, D., Kadis, J., Gall, M., \& Salovey, P. (2006). Evidence that emotional intelligence is related to job performance and affect and attitudes at work. Psicothema, 18(1), 132-138.

Loveman, G. W. (1988). An assessment of the productivity impact of information technologies. MIT Management in the 1990s, Working Paper \#88-054.

Malmi, T. (1999). Activity-based costing diffusion across organizations: An exploratory empirical analysis of $\begin{array}{lllll}\text { Finnish firms. Accounting, Organizations and Society, 24(8), 649-672. } & \text {. }\end{array}$ http://dx.doi.org/10.1016/S0361-3682(99)00011-2

Marjanovic, O. (2000). Supporting the 'soft' side of business process reengineering. Business Process Management Journal, 6(1), 43-53. http://dx.doi.org/10.1108/14637150010313339

Martinez, M. N. (1997). The smarts that count. HR Magazine, 42(11), 72-78.

Martinsons, M. G. (1995). Radical process innovation using information technology: The theory, the practice and the future of reengineering. International Journal of Information Management, 15(4), 253-269. http://dx.doi.org/10.1016/0268-4012(95)00023-Z

Matsumoto, D., LeRoux, J. A., Wilson-Cohn, C., Raroque, J., \& Kooken, K. (2000). A new test to measure emotion recognition ability: Matsumoto and Ekman's Japanese and Caucasian Brief Affect Recognition 
$\begin{array}{lllll}\text { Test (JACBART). Journal of Nonverbal Behavior, 24, 179-209. } & \text { of }\end{array}$ http://dx.doi.org/10.1023/A:1006668120583

Morris, D., \& Brandon, J. (1993). Reengineering Your Business. New York: McGraw-Hill.

Mossholder, K. W., Settoon, R. P., Armenakis, A. A., \& Harris, S. G. (2000). Emotion during organizational transformations: An interactive model of survivor reactions. Group and Organization Management, 25(3), 220-243. http://dx.doi.org/10.1177/1059601100253002

Official Gazette. (2012). The directive related to make a change in the directive about the description, features, and classification of small and medium-sized enterprises (In Turkish). Retrieved from http://www.resmigazete.gov.tr/eskiler/2012/11/20121104-11.htm (11.06.2015)

Payne, W. L. (1985). A study of emotion: Developing emotional intelligence; self-integration, relating to fear, pain and desire (theory, structure of reality, problem-solving, contraction / expansion, tuning in/coming out/letting go) (Unpublished doctoral dissertation). The Union for Experimenting Colleges and Universities, USA.

Powell, T. C. (1995). Total quality management as competitive advantage: A review and empirical study. Strategic Management Journal, 16(1), 15-37. http://dx.doi.org/10.1002/smj.4250160105

Raosoft. (2004). Sample size calculator. Retrieved from http://www.raosoft.com/samplesize.html (12.06.2015)

Reijers, H., \& Mansor, S. (2005). Best practices in business process redesign: An overview and qualitative evaluation of successful redesign heuristics. Omega, 33(4), 283-306. http://dx.doi.org/10.1016/j.omega.2004.04.012

Richards, A., French, C. C., \& Johnson, W. (1992). Effects of mood manipulation and anxiety on performance of an emotional stroop task. British Journal of Psychology, 83(4), 479-491. http://dx.doi.org/10.1111/j.2044-8295.1992.tb02454.x

Salovey, P., \& Mayer, J. D. (1989). Emotional intelligence. Imagination, Cognition, and Personality, 9(3), 185-211. http://dx.doi.org/10.2190/DUGG-P24E-52WK-6CDG

Schlaerth, A., Ensari, N., \& Christian, J. (2013). A meta-analytical review of the relationship between emotional intelligence and leaders' constructive conflict management. Group Processes Intergroup Relations, 16(1), 126-136. http://dx.doi.org/10.1177/1368430212439907

Shaw, J. D. (1999). Job satisfaction and turnover intentions: The moderating role of positive affect. The Journal of Social Psychology, 139(2), 242-244. http://dx.doi.org/10.1080/00224549909598378

Sisk, D. (2008). Engaging the spiritual intelligence of gifted students to build global awareness in the classroom. Roeper Review, 30(1), 24-30. http://dx.doi.org/10.1080/02783190701836296

Slaski, M., \& Cartwright, S. (2002). Health, performance and emotional intelligence: An exploratory study of retail managers. Stress and Health, 18(2), 63-68. http://dx.doi.org/10.1002/smi.926

Smith, I. (2005). Achieving readiness for organizational change. Library Management, 26(6/7), 408-412. http://dx.doi.org/10.1108/01435120510623764

Smollan, R. (2011). Follower perceptions of the emotional intelligence of change leaders: A qualitative study. Leadership, 7(4), 435-462. http://dx.doi.org/10.1177/1742715011416890

Sosik, J. J., \& Megerian, L. E. (1999). Understanding leader emotional intelligence and performance: The role of self-other agreement on transformational leadership perceptions. Group \& Organization Management, 24(3), 367-390. http://dx.doi.org/10.1177/1059601199243006

Srivastava, R. K., Shervani, T. A., \& Fahey, L. (1999). Marketing, business processes, and shareholder value: An organizationally embedded view of marketing activities and the discipline of marketing. Journal of Marketing, 63, 168-179. http://dx.doi.org/10.2307/1252110

Stahl, D. A. (1998). Reengineering: The key to survival and growth under PPS. Nursing Management, 29(3), 14-17. http://dx.doi.org/10.1097/00006247-199803000-00004

Stanton, S., Hammer, M., \& Power, B. (1992). From resistance to results: Mastering the organizational issues of reengineering. Insights Quarterly: The Executive Journal of Business Reengineering, 2(2), 6-16.

Steven, C., \& Ronald, B. (1993). Total Quality Management in Government: A Practical Guide for the Real World. San Francisco: The Jossey-Bass Public Administration Series. 
Sutcliffe, N. (1999). Leadership behavior and business process reengineering (BPR) outcomes: An empirical analysis of 30 BPR projects. Information \& Management, 36(5), 273-286. http://dx.doi.org/10.1016/S0378-7206(99)00027-0

Sutcliffe, S., \& Bowman, M. (2000). Beyond New Age: Exploring Alternative Spirituality. Edinburgh: Edinburgh University Press.

Talwar, R. (1993). Business re-engineering. Long Range Planning, 26(6), 22-40. http://dx.doi.org/10.1016/0024-6301(93)90204-S

Thyagarajan, V., \& Khatibi, A. (2004). BPR-A tool for managing the change. The Journal of Human Ecology, 15(1), 57-61.

Tirri, K., Nokelainen, P., \& Ubani, M. (2006). Conceptual definition and empirical validation of the spiritual $\begin{array}{lllll}\text { sensitivity scale. Journal of Empirical Theology, } & \text { 19(1), }\end{array}$ http://dx.doi.org/10.1163/157092506776901870

Tka, M., \& Ghannouchi, S. A. (2014). Comparison of business process models as part of BPR projects. Information Resources Management Journal, 27(1), 53-66. http://dx.doi.org/10.4018/irmj.2014010104

Vantrappen, H. (1992). Creating customer value by streamlining business processes. Long Range Planning, 25(1), 53-62. http://dx.doi.org/10.1016/0024-6301(92)90310-X

Vaughan, F. (2002). What is spiritual intelligence? Journal of Humanistic Psychology, 42(2), 16-33. http://dx.doi.org/10.1177/0022167802422003

Weske, M. (2012). Business process management: Concepts, languages, architectures (2nd ed.). Berlin: Springer-Verlag. http://dx.doi.org/10.1007/978-3-642-28616-2

Yang, K. P., \& Mao, X. Y. (2007). A study of nurses' spiritual intelligence: A cross-sectional questionnaire survey. International Journal of Nursing Studies, 44(6), 999-1010. http://dx.doi.org/10.1016/j.ijnurstu.2006.03.004

Zaheer, A., Rehman, K. U., \& Khan, M. A. (2010). Development and testing of a business process orientation model to improve employee and organizational performance. African Journal of Business Management, 4(2), 149-161.

Zarei Matin, H., Kheirandish, M., \& Jahani, H. (2010). Identifying and assessing the components of spiritual intelligence in the workplace, Labbafinejad hospital case study on Tehran. Public Administration Studies, $12,74-91$.

Zarei, B. (2001). Simulation for business process re-engineering: Case study of a database management system. The Journal of the Operational Research Society, 52(12), 1327-1337. http://dx.doi.org/10.1057/palgrave.jors.2601208

Zhou, J., \& George, J. M. (2003). Awakening employee creativity: The role of leader emotional intelligence. The Leadership Quarterly, 14(4-5), 545-568. http://dx.doi.org/10.1016/S1048-9843(03)00051-1

\section{Copyrights}

Copyright for this article is retained by the author(s), with first publication rights granted to the journal.

This is an open-access article distributed under the terms and conditions of the Creative Commons Attribution license (http://creativecommons.org/licenses/by/3.0/). 